\title{
Interpretation of the Quran in Contemporary India: Wahiduddin Khan's Reading of Peace and Spirituality in the Scripture
}

\author{
REIKO OKAWA 1
}

\begin{abstract}
This study examines the interpretation of the Quran (tafsir) of an Indian Muslim intellectual, Wahiduddin Khan (b.1925), written as a commentary on his translation of the Quran, The Quran: English Translation, Commentary and Parallel Arabic Text. It aims to illustrate how Khan created a peaceful understanding of the Quran in contemporary India, where a critical need to resolve the issue of violent communalism between Muslims and Hindus existed. Two main subjects are argued here: (1) the background to Khan's thought and (2) the features of his interpretation of the Quran. Khan was deeply influenced by the Islamic and Indian trends of thought in contemporary India, such as Islamism (Tablighi Jama'at), Islamic revivalism (Jama'at-e Islami) and non-violence (Gandhism), and chose his own peaceful and spiritual understanding of Islam. This background is reflected in his interpretation of the Quran, implying that the recognition of scripture provides an awareness of the inner self which leads the way to live peacefully with non-Muslims. We discuss that this interpretation of the Quran is meaningful to build a pluralistic peaceful environment inside and outside India, since it tries to avoid actual conflict between Muslim and non-Muslim while keeping the priority of the Islamic faith.
\end{abstract}

Keywords: India, interpretation of the Quran, peace, spirituality, Wahiduddin Khan

Wahiduddin Khan (Wahiddudin Khan, 1925-) has insisted on the spiritual and non-violent interpretation of Islam, now as the founder of an organization, the Centre for Peace and Spiritual International (CPS), based in Delhi, India. He is a prolific writer and develops his ideas based on Quranic verses. Particularly, his translation and commentary on the Quran, The Quran: English Translation, Commentary and Parallel Arabic Text (Khan, trans. 2016, hereinafter QTC), presents his ultimate understanding of Islam as a base of non-violent and peaceful solutions for the environment of communalism under continuous tension in India and around the globe. This book was originally a translation of the Arabic Quran into Urdu published in 1986, then into Hindu in 2008, into Arabic in 2009 and into English in 2011.

This paper aims to discuss one possible way to interpret the controversial Islamic scripture non-violently by focusing on Khan's QTC as one of the prominent products in the Muslim history of tafsir, the interpretation of the Quran. Many studies on liberal or progressive Muslims' tafsir have appeared recently (See, for example, Campanini 2010; Okawa 2013; Rahemtulla 2017). These studies have also made clear that we are seeing a new trend of tafsir flourishing in present times. A feature of this trend is many interpretations of the Quran written by minority Muslim intellectuals in the English-speaking world, such as Amina Wadud (1952-) of the United States, Farid Esack (1959-) of South Africa, and Asghar Ali Engineer (1939-2013) of India. They have a common concern about how to deal or harmonize with such liberal values as equality, pluralism and human rights. We would like to add Khan's QTC here as a tafsir which pursues the peaceful way in the Quran for Muslims to coexist with non-Muslims.

\footnotetext{
${ }^{1}$ Reiko Okawa, Ph.D., professor at the Department of International Studies, Meiji Gakuin University, 1518, Kamikurata-cho, Totsuka-ku, Yokohama, KANAGAWA, 244-8539, Japan, email: okawa@k.meijigakuin.ac.jp.
} 
Several researchers have studied Khan, and their main concerns can be divided into two contexts: modern Islamic thought in South Asia and peace-building (Halverson2012; Hermansen 2017; Mohamed 2006; Omar 2015; Sikand2004). In the former context, Khan is often compared with Abul Ala Maududi (Abu al-A'la al-Maududi, 1903-1979), the founder of the Pakistan Islamist organization, Jama'at-e Islami (Omar 1999, 2001, 2008a\&b; Troll 1982, 1998). This paper connects these two viewpoints and makes clear the modern Indian Muslim thought on peace by focusing on Khan's Quranic interpretation and comparing it with the Quranic interpretations by Abul Kalam Azad (Abu al-Kalam al-Azad, 1888-1958) and Maududi. Azad was an adviser of Mohandas Gandhi (1869-1948) and the first Minister of Education in the Indian government. First, we will investigate Khan's background in terms of his life history, Indian interpretation of the Quran, and his recognition of Gandhi, who had a great respect for the Quran and interpreted a Hindu scripture, the Bhagavad Gita, allegorically and in a non-violent way. This will make clear the background against which Khan establishes himself as a nationalist minority Muslim who would like to coexist peacefully in a Hindu majority country. This paper will then move on to examine three prominent concepts seen in QTC: scripture, inner-selfless and peaceful coexistence. Through the examination, it will be found that these elements are significant in Khan's thinking about how to live as a Muslim minority in India without conflict. This also answers the question of how it is possible to interpret peacefully scripture which includes militant or violent verses, usually thought of as the foundation of "terrorist" or "extremist" Muslims.

\section{Life of Wahiduddin Khan}

He was born in Azamgarh, India, in 1925 and educated in a Muslim traditional seminary. Prior to India's independence from British rule in 1947, he became "a staunch nationalist with Gandhian values" (Khan 2013). After completing his religious learning in 1944, he continued to study English and modern science by himself, and in 1955 started publishing books to publicly address his ideas on a new understanding of Islam, that it is the religion of peace, tolerance, coexistence and pluralism. He then established the Islamic Centre in New Delhi in 1970. The Babri Mosque incident in 1992 encouraged him to conduct a peace march to advocate harmony between Muslims and Hindus. In 2001, he established CPS International "to promote and reinforce the culture of peace through mind-based spirituality" and "under Maulana [Khan]'s patronage and inspired by his spiritual wisdom, the activities of the centre: peace efforts and inter-faith efforts to help individuals understand the importance of peace" (Khan 2013).

It should be noted that there are two significant life events for Khan in terms of the development of his thinking. One of the events is his withdrawal from Jama'at-e Islami Hind in 1962; the other is his withdrawal from Tablighi Jama'at around 1975. Jama'at-e Islami Hind is a wing of Jama'at-e Islami which was founded by Maududi in 1941. Khan regards Maududi's political interpretation of Islam as problematic, since the "political interpretation of Islam has been, and continues to be, the cause of much strife and conflict across the world" (Khan 2015: 4). Maududi is well known as a Pakistani Islamist who called for "hakimiyat-e ilahi", or the sovereignty of God on Earth in an Islamic nation. His interpretation of the Quran, written between 1942 and 1972 in Urdu (Maududi 2016), is also influential among contemporary Muslims in and outside South Asia. Although Khan joined Jama'at-e Islami Hind in 1949 and played an important role, especially as a senior administrator of the publishing house of the organization, he grew sceptical of its aim to establish an Islamic state in India following Maududi's ideology. Khan saw Maududi's thinking as a reaction to Western imperialism and he moved to seek what was "emanating from a deep, genuine spiritual quest." He decided to quit Jama'at-e Islami in 1962 as he saw the political ideology to establish an Islamic state as inappropriate for the Muslim minority in India and it was important to seek a way for Muslims and Hindus to coexist (Khan 2010: Introduction). 
Khan then moved to Tablighi Jama'at and acted there for some years, but had withdrawn from the organization by 1975. Tablighi Jama'at was established in 1927 in the Mewat region, south of Delhi, in order to prevent Muslim conversion to Hindu under the pressure of Hindu revivalism. The organization has been well known for its conservatism and revivalism of Sunnah (exemplary conduct) of the Prophet Muhammad. The non-political, spiritual tendency, focusing on personal contact and 'self' with face-to-face missionary preaching activities, had an affinity with Khan's thinking, with its emphasis on individuals' self-improvement. It also put a premium on the unique system of voluntary activity for three days, forty days or one hundred twenty days: each group of about a dozen individuals stays in mosques, prepares basic food, and spends time in prayer and mutual instruction (Ali 2012: 111-134; Metcalf 2009: 241). Khan accepts the importance of personal communication, which plays a significant role in the activity. It seems, however, that formalism led him to withdraw from the organization. While Khan agreed with Tablighi Jama'at's mission of Islamic revival, he pursued another way to revive Islam according to two important demands: "the first is related to the essence, the soul of religion" and the second the "temporal, created by circumstances" (Khan 1986: 67-68). This implies that, for Khan, the activity of Tablighi Jama'at seemed to lack the latter viewpoint-that is, adjustment to the contemporary situation.

These two withdrawals represent the speculative footstep of a significant Indian Muslim thinker/activist. After moving through two influential Islamic organizations born in South Asia, first to an extremely political Islamist approach and then back to the conservative revival Islamist approach, Khan finally reached his own place as the founder of the Centre of Islam, which developed into CPS, to circulate his idea of peace, coexistence and pluralism based on individual spiritualism. His winding career is a route taken by a Muslim intellectual of contemporary India who sincerely struggled to solve the severe difficulties between Muslims and non-Muslims.

\section{Muslim in India and the Interpretation of the Quran (Tafsir)}

Along with Egypt, South Asia has been one of the most important areas in the development of Islamic thought, especially in modern times. This is a result of the historical and cultural background of the region. Muslims in South Asia have been struggling to coexist with other religious believers, especially Hindus, since they entered the area, and confronting the power of the West, especially Britain, since it started colonization. The partition from the British Empire complicated the situation further: Muslims faced the choice of living as a minority in India, a Hindu majority country, or building a new Muslim country independent of India, which is now Pakistan. Muslim intellectuals on both sides have severely struggled to provide new theories to support their own choices and viewpoints.

Two prominent western scholars, Wilfred C. Smith and Dieter Senghaas, discussed the significance of Indian Muslims as a large minority in a Hindu majority country. Smith showed his "fundamental hopefulness about Indian Muslims", since Islam in India symbolizes "the need to construct relations with outsiders... For the Indo-Muslims are in India what the total Muslim group is in the world: an important minority" (Smith 1977: 290-291). Approximately 40 years after Smith, Senghaas also insists that in the Indian Muslim situation "the differences between Hinduism and Islam are far greater than those between Islam and Christianity"; since they have "no alternative but to maintain their old forms of local coexistence or to find new ones, events in India are of the utmost exemplary significance" (Senghaas 2002: 110-111).

This severe necessity of construction of the relationship with non-Muslims has been reflected in influential interpretations of the Quran by modern Muslim intellectuals in South Asia, including Azad, who pursued founding India with unity of Hindus and Muslims, and Maududi, who exerted himself to build a Muslim country apart from India. The interpretation of the Quran by Khan belongs to this context of minority Muslims struggling with how to live in South Asia with its Hindu majority. This context has led interpreters to focus on the issue of how to face non- 
Muslims; therefore issues of peace and strife have continued to be significant topics for discussion. The notion of strife, particularly including violence, provokes further arguments when interpreting the Quran, which contains aggressive verses on "fighting" or "killing" the enemy.

\section{Khan and Gandhi}

A very significant aspect of the development of Khan's thinking is the influence of Gandhi, since Khan developed own ideas alongside the idea of non-violence in India. As mentioned in the official description, Khan self-acknowledges as "a staunch nationalist with Gandhian values". Khan's respect for Gandhi as a nationalist who struggled for the unity of India seems to be connected to the fact that Khan insisted on "getting along with the Hindus" as a minority Muslim in India and not being a majority Muslim in Pakistan, in the context where he criticized Muhammad Iqbal (Muhammad Iqbal, 1877-1938), a poet and politician who inspired the Pakistan Movement (Omar 2001: 118). Thus, Gandhism is a key concept for Khan to be an Indian Muslim facing both violent and non-violent difficulties in a Hindu majority society. As Omar said (Omar 2001: 93; Omar 2008a: 678), Khan is both an admirer and critical of Gandhi. Khan has tried to renew and develop Gandhi's beliefs in non-violence, mutual respect, pluralism and tolerance of other religions to cease communalism violence. On the other hand, Khan does not follow Gandhi's thinking regarding the unity of religions, particularly between Hinduism and Islam, and using political activism to achieve the aim. Khan rather puts a premium on spiritual or moral improvement based on Islam; he has struggled to change people's mindset rather than the political system like Gandhi, thinking it is this spiritual improvement which makes it possible to build a peaceful society between Muslims and non-Muslims in India and thus across the globe (See also Omar 2008c: 153-163).

Khan and Gandhi also have commonality in terms of their interpretations of the scriptures. As is well known, Gandhi provided a profound and influential interpretation of the Bhagavad Gita, which decreed killing all enemies. The Bhagavad Gita, like the Quran, has been interpreted by many Hindu intellectuals from various standpoints (Minor, ed. 1986). Francis G. Hutchins describes Gandhi's interpretation as follows: "Because Indian terrorists were invoking the Gita's militant counsel to justify assassinations and bombings, Gandhi countered by proposing an allegorical interpretation for the ancient battlefield dialogue" (Hutchins 2017: 8-9). In this circumstance, Gandhi's interpretation had significant meaning in that it reread the militant verses which order the killing of all enemies from the viewpoint that the battle is "the ceaseless spiritual war" (Jordens 1986: 98) which happens in a human itself, and the object of "killing" is not a human but evilness in oneself, as the "human body is the battlefield where the eternal duel between right and wrong goes on" (Gandhi 2014: Discourse I, para. 3). As Kathryn Tidrick discusses, through such an allegorical interpretation, Gandhi reached the thought of satyagraha, or nonviolent civil resistance (Tidrick 2006: 140-141). Thus, like the Quran, the Bhagavad Gita has a wide range of interpretations and it could be thought that Gandhi represents the most peaceful place from which to understand it, like Khan.

Khan admires Gandhi for waging "political battles successfully by adopting the principle of non-violence and engaging in peaceful activism" (Khan 2012: 25). Moreover, Khan recognizes Gandhi's peaceful interpretation as a precedent for his own interpretation:

Yet along with this is the exhortation of Krishna to Arjuna, encouraging him to fight (Bhagavad Gita, 3:30). This does not mean that believers in the Gita should wage wars all the time. Mahatma Gandhi, after all, derived his philosophy of nonviolence from the same Gita. The exhortation to wage war in the Gita applies only to exceptional cases where circumstances leave no choice. But for general day-today existence it gives the same peaceful commands as derived from it by Mahatma Gandhi (QTC: xiv). 


\section{Abul Kalam Azad's Interpretation of the Quran}

This recognition of Gandhi's interpretation by Khan raises a question of how Khan interprets the Quran, which is often regarded to be war-like and aggressive against non-Muslims, allegorically and peacefully. Related to this question, what should be noted here is the fact that prior to Khan, Abul Kalam Azad interpreted the Quran. He formed a united front with Gandhi and, as J. M. S. Baljon describes, believed in "the actual existence of a Universal Religion, despite all the extant divergent rites and creeds", which is what Gandhi believed. Baljon, furthermore, points out that "it was for the purpose of exhibiting the brilliancy of the One Universal Truth mankind is so badly in need of, that Azad wrote his commentary" (Baljon 1968: 10).

Azad, well known as a modernist and secularist, struggled to create an independent India as a nation where Muslims and Hind us exist together. Azad's interpretation of the Quran, Tarjman al-Qur'an (Azad 1990), written up to Surah or Chapter 23, was originally published in 1930 and 1936, and later revised and reprinted in 1945 (Kamali 1959: 6). Sheila McDonough discussed Azad's interpretation of the Quran to "get some further clues as to how Gandhi understood the Quran" (McDonough 1994: 117), which implies that Azad had been greatly influenced by Gandhi's recognition of the scripture. However, in an interview, Khan stated that although Azad was right in his decision to stay in India and not move to Pakistan in the partition, the way of understanding Islam, in particular interpreting the Quran, is quite different from Khan's way. This is because Azad, according to Khan, was "a Muslim-oriented thinker", since "Maulana Azad was a leader of the Muslim community. His thinking was based on the Muslim community, while I believe in the universal message of Islam" (Khan 2014).

Thus, Khan's thinking developed in a contemporary Indian situation which faced severe conflict between Muslims and non-Muslims based on communalism, such as the Babri Masjid demolition in Ayodhya in 1992 and the violence or pogrom in Gujarat in 2002. During the era of colonization and partition, Muslim intellectuals such as Azad and Maududi needed to focus on how to deal with the balance between nationalism and religious faith and had to choose one country, India or Pakistan. Presently, however, Khan, having already chosen India, needs to face the new issue of how to live peacefully without violence as a minority Muslim in India and as a human being in the globalized world.

\section{Khan's Interpretation of the Quran: Recognition of Scripture}

Three main themes flow in Khan's interpretation of the Quran: how to recognize the scripture, to awaken and improve one's inner self, and to spend one's life peacefully. Firstly, in relation to the scripture, Khan insists that the Quran is definitely superior to other scriptures, including the Hindu scriptures, as well as the Jewish Torah and the Christian Bible-that is, monotheistic scriptures of the People of the Book (Ahl al-Kitab). Khan regards the Hindu scriptures as being "of wisdom and moral values", but not the word of God or revelation. This seems to be different from Gandhi, who regarded the Quran as a scripture of universal religion or truth (McDonough 1994: $11,108-110,114-115)$. Khan insists that the Torah, the Bible and the Quran were revealed by God to different prophets and originally with the same teachings or guidance, interpreting verses such as 2:74-77, 2:87-88, 2:120-121 and 3:3-4 (as an example, 2:87-88 here indicates Ayah, or Verses, 87-88 of the Second Surah, or Chapter, of the Quran). According to his interpretations of these verses, the Torah and the Bible were misinterpreted or altered, and the correct message was finally sent down to the Prophet Muhammad as the Quran. The People of the Book have not accepted the Quran, and though they "had been the bearers of divinely revealed religion on earth", their scriptures have declined to "a set of ethnic customs" (QTC: 26-27, 31-33, 43, 127).

Thus, Khan's recognition of the scripture follows the traditional Islamic creed, in common with Maududi's interpretation of 3:3, explaining in detail the Taura and the Injil. According to Maududi's interpretation, these two books, although they were the word of God, are not identified 
completely with the Old Testament and the New Testament in the present day because Jews and Christians compiled their scriptures differently from the original revealed texts (Maududi 2016 1: 224-225). Khan believes in the original unity of the word of God in the monotheistic scriptures, following Islamic conventional faith, which leads to a distinction of other scriptures, such as the holy texts of Hinduism, since for him, the latter is not the word of God, but a book of wisdom.

Even so, Khan cites other scriptures such as the Gita and the Bible to show the common ground between different religions when he tries to interpret the aggressive words of the scripture from a broader perspective. He insists that jihad does not mean violence but "peaceful struggle", and aggressive words such as 2:191 "relate, in a restricted sense, to those who have unilaterally attacked the Muslims. The above verse does not convey the general command of Islam" (QTC: xiii). After stating that all religious books have the "division of commands into different categories", Khan provides examples in references to other scripture. The first example is the Gita, which was cited above on "the exhortation of Krishna to Arjuna, encouraging him to fight (Bhagavad Gita, 3:30)". The second is related to Matthew in the Bible:

Similarly, Jesus Christ said, 'Do not think that I came to bring peace on Earth. I did not come to bring peace, but a sword' (Matthew, 10:34). It would not be right to conclude that the religion preached by Christ was one of war and violence, for such utterances relate purely to particular occasions. So far as general life is concerned, Christ taught peaceful values, such as the building up of a good character, loving each other, helping the poor and needy, etc (QTC: xiv).

Khan concludes that the "Quranic instructions of war have very limited meaning" since the Prophet battled only on occasions when no other option existed. Therefore, the aggressive verses in the Quran "were not meant to be valid for all time to come" (QTC: xiv). As seen above, Khan admits the commonality with other scriptures such as the Gita and the Bible. That Khan respects the other scriptures - not only the Torah and the Bible, but also the Gita-and cites them for comparison implies that he acknowledges the importance of both the polytheistic and the monotheistic scripture. It could be said that he, as an Indian Muslim, goes beyond the traditional Islamic faith towards a more pluralistic recognition of scripture.

\section{Importance of Allegorical Interpretation}

Khan defines the Quran, in the Introduction to $Q T C$, "a combination of lessons and admonitions, it would be even more appropriately called a book of wisdom" (QTC: xi). Furthermore, he insists that to understand the true meaning, it is necessary to interpret some of the verses allegorically: 3:7 implies that the Quran contains two kinds of verse, muhkamat (clear) and mutashabihat (ambiguous):

It is He who has sent down the Book to you. Some of its verses are clear and precise in meaning - they are the basis of the Book-while others are allegorical. Those with deviation in their hearts pursue the allegorical, so as to create dissension by seeking to explain it: but no one knows its meaning except God. Those who are firmly grounded in knowledge say, 'We believe in it: it is all from our Lord.' But only the wise take heed (QTC: 129).

Khan here translates the word mutashabihat as "allegorical", commenting that the Quran has two subjects - "the known human world" and "unseen matters" - and the latter requires allegorical interpretation; if it is not interpreted in this way, the reader cannot avoid falling into error. He further connects this need for allegorical interpretation to an acknowledgement of the limitation or imperfectness of human sensory perception (QTC: 129-130). 
As for the terms muhkamat and mutashabihat of 3:7, both Azad and Maududi insist that the former is much more significant to understand the truth and the latter is secondary (Azad 1990 2: 140; Maududi 2016 1: 226-227). Thus, it is a feature of Khan's style to put a premium on interpreting the Quran allegorically, since he believes that this is the way to approach the unseen issues mentioned in the scripture. Such a way of interpretation belongs to the same category as Gandhi's allegorical interpretation, as mentioned before. It pursues the way of coexistence in the contemporary world through interpreting the scriptures spiritually, focusing on the inner or hidden meaning.

\section{Awareness of Inner Self}

The second feature of Khan's interpretation is putting a great premium on man's inner self. In the introduction to $Q T C$, he argues the relationship between the inner spirit and the realization of God when interpreting 5:83. He derives the concept of "ma'rifah", or recognition of truth, from "the Truth they recognize" (ma 'afaru min al-haqq) in this verse, as below:

When they listen to what has been sent down to the Messenger, you see their eyes overflowing with tears, because of the Truth they recognize. They say, 'Our Lord, we believe, so count us among those who bear witness (QTC: 316$)$.

In Khan's opinion, the inner spirit plays the most important role in building "the Islamic personality" and it is the Quran that produces the inner spirit. Khan calls this production the "intellectual revolution," which is also called ma'rifah, or "realization of truth." That both Azad and Maududi do not show concern about this verse suggests the importance of this verse for Khan; thus, he regards the Quran as a book which brings about an intellectual transformation of the human mind (QTC: xii).

Khan often reads the Quranic verses by interpreting them spiritually or taking them to indicate the human's inner self. He discusses in interpreting 2:2-5 that "This is the Book; there is no doubt in it. It is a guide for those who are mindful of God, who believe in the unseen...". According to Khan's interpretation, people who are eager to be guided by the Quran and to search for truth can reach the stage of "complex-free souls", without "rigidity, convention or prejudice"; searching for truth opens "the closed faculties of his own inner self" and brings about recognition of "the unseen" hidden behind the present world (QTC: 4). Khan's concept of "complex-free souls" is a significant mental condition, according to Khan's interpretation. He puts a premium on tazkiah, or "purification" of the soul, explaining it as interpreting "a messenger....to purify them (rasul...yuzakki-him)" from 2:129. Making a purified soul from "all negative influence" around their circumstances and being full of "love for and devotion to God" is the final aim of a prophet (QTC: 48).

Khan, furthermore, emphasizes the importance of using "insight" to understand the Quran. In interpreting 2:129-“Our Lord, send forth to them a messenger of their own to recite Your revelations to them, to teach them the Scripture and wisdom, and purify them..."-he regards "wisdom" or "al-hikma" in Arabic here as "insight", which gives birth to a high stage of consciousness:

When he moulds himself according to the teachings of the Quran, the light of insight burns within him, producing a sublime level of consciousness. This enables him to arrive at right conclusions in all matters as desired by God (QTC: 48).

On the other hand, Maududi interprets the "unseen" as what human senses are not able to perceive, such as God, angels, revelation, Heaven and Hell, and stresses the importance of believing in them. He also defines the purification of "beliefs, ideas, deeds, habits, customs, 
culture, politics, in short, every aspect of life" (Maududi 2016 1:110). He thus does not go so far as to emphasize the innerness of soul like Khan.

$$
\text { Importance of "the Spirit of God-Fearing (Taqwa)" and Spiritual Reform }
$$

Khan argues the prevalence of "the spirit of God-fearing (taqwa)", interpreting verse 2:281 which orders Muslims to fear (ittaqu) the Last Day:

Fear the Day when you shall be made to return to God; then every soul shall be paid in full what it has earned; and they shall not be wronged (QTC: 122).

According to Khan, taqwa is a more significant reform than social reform from the aspect of law, which is discussed just before this verse. He insists here that without individuals having the spirit of God-fearing, it is not possible to implement the Islamic system; therefore, realization or reform of the individual comes first and social reform is secondary (QTC: 121-122).

It could be said that reading the message of spiritual reform into this verse shows Khan's uniqueness in his interpretation of the Quran, compared with the fact that Azad and Maududi do not provide such an interpretation. For Khan, improvement of the individual spirit precedes social reform; this appears to imply that Jama'at-e Islami's aim of establishing an Islamic state is secondary to individual spiritual awareness. Furthermore, Khan details the stages of reform when interpreting 3:164:

God has conferred a great favour on the believers in sending a Messenger from among themselves, to recite His revelations to them, and purify them, and teaches them the Book and wisdom, for before that they were surely in manifest error" (QTC: 182).

He divides the stages of reform into four steps: (1) to awaken the signs of God in people's "mental make-up"; (2) to purify people by direct communication; (3) to teach Islamic law on how to live in this world; and then (4) to deliver the secrets of religious truth (QTC: 182). Although these stages are, in particular, meant to preach Islam to non-Muslims, what is noteworthy here is that the stages start with a mental or spiritual awareness. The fact that Azad and Maududi do not relate this verse to such an argument on spiritual reformation highlights Khan's strong concern about spirituality in his interpretation.

\section{Spiritual Meaning of Fasting and Fighting}

The tendency to interpret spiritually can be seen clearly when Khan shows his understanding of the verses on fasting (2:183-184):

Believers, fasting has been prescribed for you, just as it was prescribed for those before you, so that you may guard yourselves against evil. Fast for a specified number of days, but if any one among you is ill or on a journey, let him fast the same number of days later. For those who can fast only with extreme difficulty, there is a way to compensate-the feeding of a needy person. But he who does good of his own accord shall be well rewarded; but to fast is better for you, if you only knew (QTC: 72).

He divides the practice of fasting into physical fasting and "the spirit of fasting": the former is a normal fasting practised for only one month every year, but the latter is, according to Khan, long lasting. Fasting makes it possible to understand how to fulfil one's "spiritual 
obligations in the turmoil of the materialistic world" and attain "peace of mind". During the month of Ramadan, in particular, one concentrates on God and avoids bad behaviours such as lying or gossiping, which provide improvement to one's character: one's "inner self" approaches closer to the devotional stage day by day, the soul being elevated to "a condition of superior spiritual bliss" (QTC: 72). Azad briefly shows his idea that the object of fasting is to improve the mind of man, such as restraint through purification (Azad 1990 2: 76). Maududi does not mention any spiritual or mental effort in relation to fasting, focusing on the historical background of this revelation in the era of the Prophet Muhammad (Maududi 2016 1: 135, 138).

Based on Khan's high concern about spirituality, the word "qatilu", which is usually translated as "fight" or "kill", is interpreted in a very spiritual and peaceful way in 9:123, linking to the concept of "self" and "taqwa". Khan translates this verse as "Believers! Fight against those deniers of the truth who are near you. Deal firmly with them. Know that God is with those who fear Him". The word "fight" or "qatilu" is often translated as "kill" and the last word "those who fear Him" or "al-muttaqin", implies the those who pursue taqwa to God.

Azad and Maududi interpret this verse to mean the physical military fighting against, respectively, the Arab Christians and the Romans of the neighbouring countries and hypocrites in Muslim society (Azad 1990 3: 79; Maududi 2016 2: 253). These two ways of interpretation limit the object of "fighting against" and ban an unconditional attack on all kinds of unbelievers. Khan, on the other hand, interprets this verse more spiritually. He regards "fighting" as a struggle or an effort with two steps: "the very first struggle should be undertaken with a man's own 'self', because the thing nearest to a man is his 'self". It is after this action that "all action against aggressors should be carried out in fear of God (taqwa)", as "fear of God is a meeting point between God and His subject" (QTC, 561). Thus, Khan interprets the word usually thought to mean physical fighting as a process of struggle, where to improve one's inner self is the first and more significant duty, and to act against oppressors outside the inner self is secondary and should be conducted always with taqwa, fear of God, inside one's self.

\section{Living Peacefully: Jihad and Fitnah}

Khan's interpretation places great emphasis on how to live peacefully. The Quran includes many verses which might be read as suggesting or commanding that Muslims fight or kill enemies, or non-Muslims. As Khan states, an idea that the Quran is a book of jihad "by means of violence" has been widespread through the media. Such a prevailing recognition is generally based on people regarding "jihad" as a holy war, or a religious duty of Muslims to kill non-Muslims unconditionally. He, however, citing 25:52, insists that this "is based on a misunderstanding", and the meaning of jihad is "peaceful struggle" (QTC: xiii). This verse is translated by him as follows in two slightly different ways in two different places; the point is, however, that he translates "jihad kabir" as "greater jihad" or striving "with the utmost strenuousness":

Do greater jihad (i.e. strive more strenuously) with the help of this [Quran] (QTC: xiii).

...so do not yield to those who deny the truth, but strive with the utmost strenuousness by means of this [Quran, to convey its message to them] (QTC: 1111).

Khan interprets this verse as ordering "a peaceful struggle to spread the word of God", which is the real and greatest jihad; even if such peaceful efforts become difficult because of enemies, believers should continue the struggle to preach and spread the teaching of the Quran (QTC: 1111). Thus, for him, jihad is an absolutely peaceful endeavour, a mission to spread the Quran to non-Muslims. Maududi, on the other hand, though interpreting "jihad kabir" similarly- 
the utmost endeavour - suggests all kinds of ways such as using "one's tongue, pen, wealth, life and every other available weapon" (Maududi 2016 3: 431), which implies the use of violence.

In addition to the concept of jihad, Khan shows his peaceful interpretation of the notion of qital, or "killing" or "fighting", by limiting the circumstances where violence is used. 2:190-193 includes commandments to fight (qatilu or uqtulu) "against those who wage war against you" with two conditions of not committing aggression and the non-existence of fitnah, or "religious persecution".

And fight in God's cause against those who wage war against you, but do not commit aggression - for surely, God does not love aggressors. Slay them wherever you find them [those who fight against you]; drive them out of the places from which they drove you, for [religious] persecution is worse than killing. Do not fight them at the Sacred Mosque unless they fight you there. If they do fight you, slay them-such is the reward for those who deny the truth - but if they desist, then surely God is most forgiving and merciful. Fight them until there is no more fitna[ $h]$ [religious persecution] and religion belongs to God alone. If they desist, then let there be no hostility, except towards aggressors (QCT: 76).

"Fitnah" is regarded as having a wide range of implications, such as "sedition", "civil strife" or "temptation". Khan interprets these verses, mentioning the historical situation of the Prophet Muhammad: although Muslims had migrated from Makkah to Madinah to seek a peaceful life, Makkan opponents attacked them repeatedly:

When aggression has already been committed by opponents, believers are obliged to defend themselves. Initiating hostilities is not permitted for Muslims. Only defensive war is permitted in Islam. Even defensive war has to be openly declared by an established state (QCT: 76).

Furthermore, Khan states his interpretation of verse 193 which ordains that qital must end when fitnah against the believers finishes. His interpretation of this verse is more understandable when considering it alongside 8:39, which addresses the same issue concerning qital and fitnah. He cites a tradition of 'Abdullah ibn 'Umar, a companion of the Prophet Muhammad, as the basis of his own interpretation, according to which fitnah does not mean "political infighting" but "the religious coercive system" (QTC: 499), which is, in the context of the tradition, religious oppression of Muslims by the Makkan. Therefore, fitnah is temporary and limited in terms of duration, and when it is over, the Quran does not permit violence or war: "except in cases where self-defence had become inevitable, the Quran did not give permission for violence" (QTC: 76), as 'Abdullah ibn "Umar rejected joining the political conflict between the Umayyads and 'Abdullah ibn Zubayr, who declared a caliphate in rivalry with the dynasty (QTC: 499).

When it comes to the interpretations by Azad and Maududi of 2:190-193, they admit having a war more than Khan, although all three share the notion that war is wrong. Azad emphasizes the necessity of justice and rightness even in time of war. However, he insists that "war is an evil. But disorder is much worse". According to Azad, "disorder" is the situation where freedom of conscience or religion is deprived violently, which seems to mean fitnah. It is then that war should be required to protect "the right of freedom of conscience" (Azad 1990 2: 81). Maududi, admitting the necessity of war, argues the appropriateness of war, interpreting that reasons should be defence against aggression or obstruction of opponents, and war should be conducted humanely (Maududi 2016 1: 145-146). It could be said, then, that Khan interprets the qital and fitnah verses as non-violently as is possible. 


\section{"The Verse of the Sward"}

The well-known "Verse of the Sword" (9:5) decrees killing the polytheist wherever found, and is often regarded as a symbolic verse to prove "the war-likeness" of Islam. It says:

When the forbidden months have passed, kill the polytheists [who are at war with you] wherever you find them. Take them captive, and besiege them, and lie in wait for them at every place of ambush. But if they repent, and take to prayer regularly and pay the alms, then let them go their way. God is forgiving and merciful (QTC: 515).

Both Khan and Azad interpret this verse remarkably restrictively in terms of violence, while Maududi focuses on the issue of conditions of who should be attacked without doubting the generality of the verse (Maududi 2016 2: 180). Azad limits the target of war only to polytheists, like the Arab non-Muslim tribes who severely obstructed the mission of the Prophet Muhammad, saying "the verses are not addressed to the polytheists in general" (Azad 1990 3: 3). This kind of interpretation by Azad could be useful to avoid direct conflict between Muslims and polytheists in modern India as well, and is followed by Khan.

According to Khan, this verse is not "about an ordinary fight" against "those who denied the truth due to their rejection of the Prophet", since "this was a special principle of God which related to the addressees of the Prophet and not to the general people". Thus the first half of this verse states "the order being so severe". Khan, however, tries to extract from the latter half the more tolerant message for the present day. It says that even if, after long preaching, a non-believer "does not accept Islam, he should be led back to his place of residence under their protection" (QTC: 515$)$. This view would suggest Khan's strong intention to coexist with non-Muslims without violence, keeping deep and long-term patience, as he says that "if a man indulges in transgression unknowingly or out of ignorance, he will be treated with all possible lenience until his unawareness or ignorance is rectified" (QCT: 516).

\section{Society without Violence}

In contrast to the Verse of the Sword, 5:32 is a verse renowned for declaring the dignity of human life:

...whoever killed a human being-except as a punishment for murder or for spreading corruption in the land-shall be regarded as having killed all mankind, and that whoever saved a human life shall be regarded as having saved all mankind...(QTC: 289$)$.

Both Azad and Maududi insist upon the sanctity of human life and the importance of kindliness to all humanity (Azad 1990 2: 292; Maududi 2016 1: 447). In addition to this, a remarkable feature of Khan's translation is that he links this verse to a reflection on social issues, based on the fact that modern Indian society has shown a history of highly divisive communal violence. He states:

In a society, the tradition of respect for each other's life is formed as a result of a long history, and once this tradition is violated, it will be a very long time before it can be revived. Those who establish the tradition of violence in a society are the worst enemies of that society (QTC: 289).

Furthermore, Khan interprets the militant Quranic verses in a non-violent way. He also presents his own thoughts on how to live peacefully with non-Muslims by interpreting verses of 
the scripture. For example, he understands that 41:33-36 suggests the way of reconciliation with the enemy.

Who speaks better than one who calls to God and does good works and says, 'I am surely of those who submit'? Good and evil deeds are not equal. Repel evil with what is better; then you will see that one who was once your enemy has become your dearest friend, but no one will be granted such goodness except those who exercise patience and self-restraint-no one is granted it save those who are truly fortunate. If a prompting from Satan should stir you, seek refuge with God: He is the All Hearing and the All Knowing (QTC: 1428).

Although Maududi admits in his interpretation that good behaviour towards one's opponent is useful to build a good relationship, he adds that this is not a general principle, since there are also wicked people who never change or react to such good treatment (Maududi 2016 4: 492-493). In contrast to Maududi's suspicious view, Khan goes so far as to read the message of "unilateral good behaviour" in the verses, insisting upon avoiding revenge on an opponent who has done something wicked by exercising patience and eradicating "the urge to retaliate." He says, "even if people are not good to him, he should be good to them" (QTC: 1428).

To conclude, as has been seen here, Khan could be regarded as having responded to the serious issue of Indian Muslims on how to live as a large minority to a great extent. In his life, he rejected the way of Islamism, Jama'at-e Islami, and Islamic revivalism, Tablighi Jama'at, after long personal scrutiny of them. Then he chose-or, more precisely, established by himself-an organization to pursue and circulate the thoughts and activities of peace and spirituality. CPS was founded to show the middle or realistic way to live with non-Muslims under the influence of Gandhi's non-violence philosophy: this is Khan's answer as a minority Muslim intellectual in contemporary India reflecting the global circumstances.

From the viewpoint of the history of the Quranic interpretation (tafsir) in South Asia, Khan's interpretation, deeply reflecting his own ideas and containing messages to minority Muslims, provides three main remarkable themes, being scripture, spirituality and peace. The scripture is, through allegorical interpretation, a medium to guide the spiritual awareness or improvement of readers'/listeners' inner self. After that, they would become more obedient to God and tolerant towards others, or non-Muslims, focusing on a peaceful struggle, or jihad, to preach Islam to others rather than being involved with violence. It is such believers who can build a peaceful relationship with others by keeping their mind patient and fearing God. This interpretation of the Quran appears to follow that by Azad, who pursued the unity of Muslims and Hindus with the support of Gandhi. Azad's interpretation has a more pluralistic and tolerant tendency than Maududi's; compared with Khan's, however, it should be said that it did not go so far as to present a spiritual notion of living together with non-Muslims. It was Khan who followed Gandhi's allegorical interpretation of the scripture to reveal the hidden spiritual meaning. This difference of Khan's interpretation from those of Azad and Maududi is largely based on their social and historical backgrounds: Khan developed his idea after the partition, the others before or during it. Azad and Maududi stressed the importance of political social reform, whether focusing on the national unity of India or building a separate Muslim nation, while Khan puts a great premium on spirituality, keeping a distance from political activity which could provide conflict in real life. It could be said that he chose the place that seems to be most realistic or valuable to live in contemporary India, avoiding violence or conflict, but keeping the Muslim identity.

Khan's interpretation of the Quran must not have developed outside India, where Muslims have been facing non-Muslims historically for a long time with or without violence. Furthermore, in modern history, Muslims have been forced to make a severe choice to live as a majority or a minority. Those who chose to live as a minority, including Khan in India, could get 
the opportunity to think of themselves as Indian citizens who also have Gandhi's legacy of nonviolent thought. Thus, Khan is a mixture of Muslim-ness and Indian-ness; therefore he could develop the thought which has a value outside India. Since he insists on retaining his Muslim identity, avoiding integration into a unity of religion, or universal religion, this thinking could be of more value and also fascinate Muslims outside India who are also a minority and seeking a way to co-exist with non-Muslims.

\section{References}

Ali, Jan A. 2012. Islamic Revivalism Encounters the Modern world: A Study of the Tabligh Jama'at. New Delhi: Sterling.

Azad, Maulana Abul Kalam. 1990. The Tarjuman al-Qur'an. Trans. \& ed. by Syed Abdul Latif. 3 Vols. New Delhi: Kitab Bhavan.

Baljon, J. M. S. 1968. Modern Muslim Koran Interpretation (1880-1960). Leiden: E.J. Brill.

Campanini, Massimox. 2010. The Quran: Modern Muslim Interpretation. Trans. by Caroline Higgitt. London: Routledge.

Gandhi, Mohandas K. 2014. The Bhagavad Gita According to Gandhi. Trans. by Mahadev Desai. [Kindle]. Floyd, VA: Sublime Books.

Halverson, Jeffry R. 2012. Searching for a King: Muslim Nonviolence and the Future of Islam [Kindle]. Washington D.C.: Potomac Books.

Hermansen, Marcia. 2017. Muslim Theologians of Nonviolence. In Ednan Aslan and Marcia Hermansen (eds.). Religion and Violence: Muslim and Christian Theological and Pedagogical Reflections (pp. 147-162). Wiesbaden: SpringersVS.

Hutchins, Francis G. 2017. Gandhi's Battlefield Choice: The Mahatma, the Bhagavad Gita, and World War II. New Delhi: Manohar.

Jordens, J. T. F. 1986. Gandhi and the Bhagavadgita. In Robert N. Minor (ed.), Modern Indian Interpreters of the Bhagavadgita (pp. 88-109). Albany: State University of New York Press.

Kamali, S. A. 1959. Abul Kalam Azad's Commentary on the Qur'an. Muslim World 49(1): 5-18.

Khan, Maulana Wahiduddin. 1986. Tabligh Movement. New Delhi: Islamic Centre.

Khan, Maulana Wahiduddin. 2010. Jihad, Peace and Inter-community Relations in Islam [Kindle]. Trans. \& ed. by Yoginder Sikand. New Delhi: Rupa \& Co.

Khan, Maulana Wahiduddin. 2012. The True Jihad: The Concepts of Peace, Tolerance and NonViolence in Islam. New Delhi: Goodword Books.

Khan, Maulana Wahiduddin. 2013. The Quran for All Humanity [Kindle]. Trans. Farida Khanam. New Delhi: Goodword Books.

Khan, Maulana Wahiduddin. 2014. Interview with Tomas Lindgren, Swedish Academic (March 1, 2014)". https://www.cpsglobal.org/content/interview-tomas-lindgren-swedish-academicmarch-1-2014. Retrieved: February 20, 2019.

Khan, Maulana Wahiduddin. 2015. The Political Interpretation of Islam. Noida: Goodword Books.

Khan, Maulana Wahiduddin (trans). 2016. The Quran, English Translation, Commentary and Parallel Arabic Text. Ed. by Farida Khanam. New Delhi: Goodword Books.

Maududi, Sayyid Abul A'la, 2016. The Meaning of the Qur'an. Trans. by Ch. Muhammad Akbar \& ed. by A.A. Kamal. 6 Vols. Lahore: The Islamic Publications.

McDonough, Sheila . 1994. Gandhi's Responses to Islam. New Delhi: D. K. Printworld.

Metcalf, Barbara D. 2009. Jihad in the Way of God: A Tablighi Jama'at Account of a Mission in India. In Metcalf. Islam in South Asia in Practice (pp. 240-249). Ed. by Barbara D. Princeton, NJ: Princeton University Press.

Minor, Robert N. (ed.) 1986, Modern Indian Interpreters of the Bhagavadgita. Albany, NY: State University of New York Press.

Mohamed, Seedat. 2006. Wahiduddin Khan and Peace in Contemporary Islamic Thought. South African Journal of Psychology 36(4): 830-850. 
Okawa, Reiko. 2013. Contemporary Muslim Intellectuals who Publish Tafsir Works in English: The Authority of Interpreters of the Qur'an. Orient, 48: 57-77.

Omar, Irfan A. 1999. Islam and the Other: The Ideal Vision of Mawlana Wahiduddin Khan. Journal of Ecumenical Studies 36(3/4): 423-438.

Omar, Irfan A. 2001. Rethinking Islam: A Study of the Thought and Mission of Maulana Wahiduddin Khan. PhD Thesis. Temple University.

Omar, Irfan A. 2008 a. Towards an Islamic Theology of Nonviolence: A Critical Appraisal of Maulana Wahiduddin Khan's View of Jihad (Part I). Vidyajyoti Journal of Theological Reflection 72(9): 671-680.

Omar, Irfan A. 2008 b. Towards an Islamic Theology of Nonviolence: A Critical Appraisal of Maulana Wahiduddin Khan's View of Jihad (Part II). Vidyajyoti Journal of Theological Reflection 72(10):751-758.

Omar, Irfan A. 2008 c. Mahatma Gandhi and Wahiduddin Khan on Nonviolence and Jihad. In Michael K. Duffey and Deborah S. Nash (eds.). Justice and Mercy Will Kiss: Paths to Peace in a World of Many Faiths (pp. 153-163). Milwaukee, WI: Marquette University Press.

Omar, Irfan A. 2015. Jihad and Nonviolence in the Islamic Tradition. In Irfan A. Omar and Michael K. Duffey (eds). Peacemaking and the Challenge of Violence in World Religions [Kindle]. Malden, MA, Oxford: Blackwell.

Rahemtulla, Shadaab. 2017. Quran of the Oppressed: Liberation Theology and Gender Justice in Islam. Oxford: Oxford University Press.

Senghaas, Dieter. 2002. The Clash within Civilizations: Coming to Terms with Cultural Conflicts. London \& New York: Routledge.

Sikand, Yoginder. 2004. Peace, Dialogue and Dawah: An Analysis of the Writings of Maulana Wahidudidn. In Yoginder Sikand. Muslims in India since 1947: Islamic Perspectives on InterFaith Relations (pp. 49-66). London and New York: Routledge Curzon.

Smith, Wilfred Cantwell. 1977. Islam in Modern History. Princeton, NJ: Princeton University Press. Tidrick, Kathryn. 2006. Gandhi: A Political and Spiritual Life. London \& New York: L. B. Tauris.

Troll, Christian W. 1982. The Meaning of Din: Recent Views of Three Eminent Indian Ulama. In Christian W. Troll, (Ed.). Islam in India: Studies and Commentaries (pp. 168-177). New Delhi: Vikas Publishing House.

Troll, Christian W. 1998. Divine Rule and its Establishment on Earth: A Contemporary South Asian Debate. In John J. Donohue \& Christian W. Troll (eds.). Faith, Power and Violence: Muslims and Christians in a Plural Society, Past and Present (pp. 223-239). Roma: Pontificio Institute Orientale. 